\title{
La communauté juive organisée face à l'engagement pro-palestinien (1973-1982)
}

Catherine Massange et Jean-Philippe Schreiber

\section{(2) OpenEdition \\ 1 Journals}

Édition électronique

URL : http://journals.openedition.org/cmc/289

DOI : $10.4000 / \mathrm{cmc} .289$

ISSN : 2684-3080

Éditeur

Fondation de la Mémoire Contemporaine

Édition imprimée

Date de publication : 1 octobre 2018

Pagination : 145-181

ISSN : 1377-1256

\section{Référence électronique}

Catherine Massange et Jean-Philippe Schreiber, «La communauté juive organisée face à

l'engagement pro-palestinien (1973-1982) », Les Cahiers de la Mémoire Contemporaine [En ligne], 13 |

2018, mis en ligne le 05 novembre 2019, consulté le 08 septembre 2020. URL : http://

journals.openedition.org/cmc/289; DOI : https://doi.org/10.4000/cmc.289 


\section{Surviving Hitler An Antwerp Jew's Compelling Testimony}

\section{Jeffrey Kleiman}

This brief article represents some of the principal episodes that Alter Kleiman recorded while in hiding from 1942-19441. These serve as a summary and analysis of his work. The original memoir, published in Tel Aviv (1970), appeared in Yiddish, titled On Foreign Soil (Oyf Fremder Erd). Based on my recent translation, Kleiman offers us some narrative of his experiences as he tried to navigate the rise of antiSemitism before the war, struggled to provide for his family through the German occupation, and, after the death of his family, remained lucky enough to find shelter in Charleroi to survive until liberation.

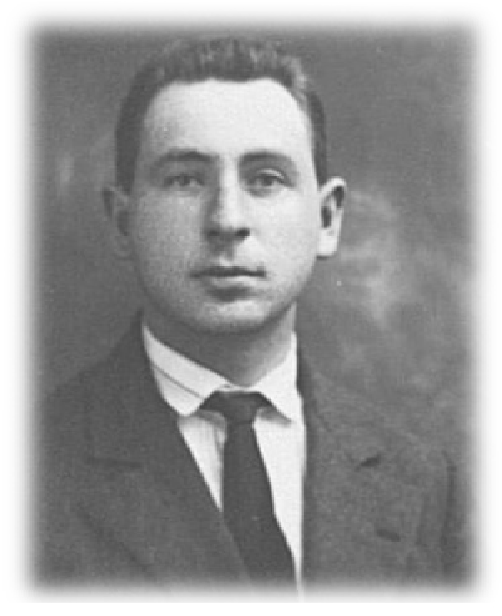

Alter Kleiman

His Eastern European origins posed no problems until the years shortly before the onset of war; the subsequent forced labor, murder of his family during the German occupation, survival in hiding, and final reemergence in an attempt to rebuild his life in post-war Antwerp brought a complete reassessment of his life in Belgium. He titled his memoir On

\footnotetext{
1 The author of this article is not related with Alter Kleiman (also written Klajman).
} The common name first stimulated interest in the work, however, it is serendipitous. 
Foreign Soil that, at first, referred to his initial migration ${ }^{2}$. By war's end, however, Belgium remained that foreign soil. A land bereft of promise, a graveyard, a place unwelcoming to Jews. Antwerp had become repugnant. The entire city repelled him as the home to suffering and sorrow. The disappointment and bitterness of his experiences reflected the lives of thousands, yet through his memoir, we have a man that has shared the overwhelming tragedy for the years before, during and after the war. If we sought a voice to grant us some insight to these years, Kleiman's would provide a solid starting point.

\section{A new life in Antwerp}

Driven out of Poland by the virulent anti-Semitism in the mid-1920s, he sought refuge among the large Eastern European Jewish community of Antwerp. He embraced both Belgium and Antwerp as places where people « know nothing about chauvinism. They make a living and conduct business with the Jews ». Continuing that « Belgians and Jews adapt to one another », he further wrote, « The separate religions make no difference, neither do dress or politics. $»^{3}$ Especially of note to him became the registration process for foreigners at the local police station.

\footnotetext{
2 A. Kleiman, Oyf fremden erd, Tel Aviv, 1970 ; this memoir stands as a highly useful complement I. Rosengarten, Overleven. Relaas van een zestienjarige joodse Antwerpenaar, Antwerp-Amsterdam, 1996 (Transl. : Survival : the story of a sixteen-year old Jewish Antwerp boy, Syracuse, 1999). There is significant overlap between the two ; however, Rosengarten's narrative regarding Antwerp ends in 1942 after his arrest in a return trip from Charleroi. Kleiman's experiences for the years 1937-1942 are more detailed. They also differ in that Rosengarten returned to rebuild a life after the war in Antwerp. Kleiman remained for five years and then made Aliyah to Israel, but common language about bitterness and the end to all family connections color both narratives.
}

${ }^{3}$ A. Kleiman, op. cit., p. 15. Pagination refers to the original Yiddish version. 
There hung a sign, in Yiddish, directing him to the correct location. Once there his optimism swelled further upon talking with the police bureaucrat who spoke in a broken, but comprehensible, Yiddish. Adding to his hopes as he returned outside, he saw another sign in Yiddish announcing the blessing of the New Moon, an occasion of note in the Jewish calendar ${ }^{4}$.

Praising the physical safety for Jews in Antwerp when compared with Warsaw, Kleiman created a good life for himself, starting a small green grocer's business, working slowly to expand business and his income. Within a few years afterward, he married Zysla Szechtman from Pulawy, Poland and a few years after that, his family grew. The birth of a daughter, Maria Martha in 1929 coincided the arrival of his parents, Benjamin and Elki Chinda Kleiman, whom he brought from Garwolin, Poland

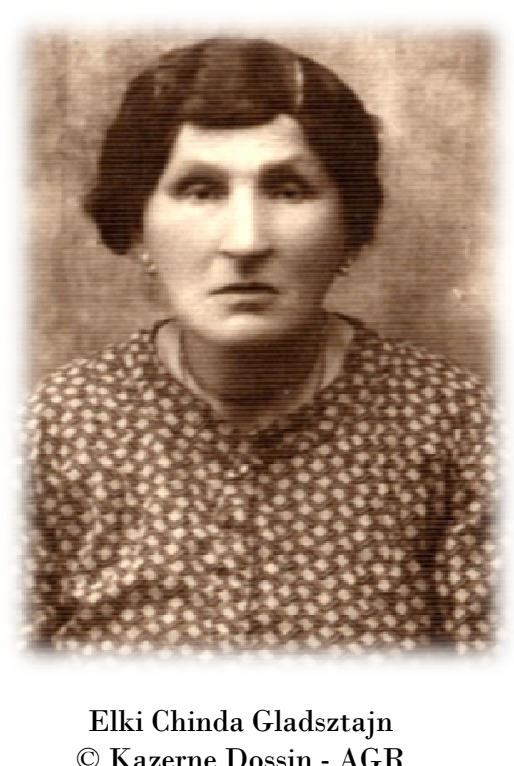
to live in Antwerp. The business grew until he finally occupied a building in Borgerhout in the Somersstraat, using the ground floor as his business and the two floors upstairs. His parents settled nearby at 163 Kroonstraat.

Life moved along well until the late $1930 \mathrm{~s}$, when an increased anti-Semitism permeated Antwerp. The numbers of refugees

${ }^{4}$ Ibid., p. 14. 
from Germany had raised the visibility of the Jewish community there by 1938 and young men dressed in Flemish nationalist party uniforms, with high black boots gathered in the Charlottalei, shouting out insults to passing Jews such as : « Get out of Belgium! Go to Palestine! » He blamed their presence on the Flemish nationalist movement born after the First World War further arguing that the release of a Flemish nationalist leader after the First World War had emboldened them after the rise of Hitler. These nationalists, along with the Nazis, « were the first to ride the Jewish hobbyhorse $\aleph^{5}$.

Kleiman also noted that people who had been quiet about voicing their prejudices no longer felt the need to keep quiet. Going to his long-time lawyer in order to write some sort of a formal request to the tax bureau, the lawyer wrote out a draft for Kleiman to sign. When Kleiman asked to read the document before signing, the lawyer evidently disliked an apparent lack of trust in his work and began to complain about the Jews who had "twisted the Belgian businessmen » and then moved along further on to argue that soon the Jews would equal or outnumber the native Belgians. Later on that same year, 1938, while tending shop he noted that his freight bicycle (triporteur) had disappeared.

The situation only worsened over time. Once again, the delivery bicycle served as the focus of confrontation. A well-established flour merchant came into the grocery store to tell Kleiman that the flour truck had hit and damaged the delivery bicycle. Leaving his name and other relevant details, he told Kleiman to present this as evidence to the court and receive compen-

5 Ibid., p. 19. 
sation from the insurance company. Although the insurance claims went uncontested, despite the responsible party's acknowledgement of damages and willingness to make good, once in court, no restitution took place. After months of stopping by his lawyer's office and receiving word to wait and return later, he finally learned what had transpired in the courtroom. Somehow the judge turned the tables, so that Kleiman became the defendant, with significant fines of 385 Belgian francs levied against him. One must wonder exactly how his lawyer represented the case.

Situations in Antwerp for the Jewish community deteriorated as refugees tried to pour over the Belgian border in the wake of Kristallnacht. Border police turned away thousands under threat of arms, despite braving unusually cold and snowy weather. Many, who had not received credentials from Jewish organizations vouchsafing care, found themselves stranded in a no-man's land between Belgium and Germany. Others, in the thousands, arrived in Antwerp, pressing local resources to the limit. Kleiman noted how many people took advantage of the situation by increasing rents for established dwellings while opening up previously unused garrets, cellars, or out-buildings, many began to sleep out in the park. Food costs skyrocketed in the face of a sudden demand even as the quality became increasingly inconsistent.

\section{The Exodus}

Despite the pressure built within Antwerp, Jews from Germany continued to seek refuge until 1940. Word of the invasion in May 1940 sent Kleiman, his family, along with several stran- 
gers, including a newlywed couple in a headlong flight to the imagined safety of France. In their flight to the Channel Coast, he reported clogged roads, fights over gasoline, pleading and bargaining with the military to spare some fuel to help them continue the trip. Ominously enough, in the escape toward the coast with hopes to find a boat to England, Kleiman's crowded vehicle encountered a division of well-equipped British soldiers. Singing confidently, using large trucks to haul anti-aircraft guns, they helped provide the Kleiman car with some needed gasoline. He later learned they were en route to Dunkirk.

Shortly afterwards, the tension became palpable as the carload of Antwerp refugees reached the French border, were almost denied entry, and then, before going along to many more kilometers, the auto ran out of gasoline again. Ingeniously siphoning gasoline from an abandoned gas station where the pumps had been removed, the group continued until reaching Calais. By a matter of hours, they had missed the last boat to cross over to England. Upon inquiry, a naval official told them that no more ships would depart the rest of the day due to uncertainty regarding safety. The party hunkered down, sleeping in and around the car, hoping that the next day might bring escape. No luck at all. Driving further through northern France, the group encountered a German roadblock. Their hopes dashed by the successful German occupation of France, they turned back and debated what to do next. Ultimately, they decided there remained no option other than a return to Antwerp. 


\section{In Nazi-occupied Antwerp}

Kleiman returned home to reopen his business, but found that all Jewish businesses had been shuttered, their wares confiscated under the pretext that leaving the goods unattended only created a health hazard by drawing mice and other vermin. Throughout the remainder of 1940 and into the next year, Kleiman's life grew more difficult. As an observant orthodox Jew, he faced serious problems as the Germans immediately proscribed religiously ordained slaughter of animals (kosher kashrut) ${ }^{6}$. The year closed out as a trainload of Jews left Antwerp under force of arms, shipped to Limburg under the German orders of December 11. He described how more than three thousand Jews gathered in Antwerp in frigid weather; the crying and confusion of the crowd gathered in Antwerp highlighted the awful physical conditions posed by the deep of snow that lay all about while temperatures plunged to $-22 \mathrm{C}$. 7

The future of Antwerp's Jews played out in April 1941 as a local version of the Kristallnacht pogrom brought shattered businesses and promoted vandalism, along with random personal violence in its wake. Kleiman inadvertently met up with the perpetrators en route to the Jewish district and recalled his encounter: walking through the city, he found himself at the De Keyserlei by the main railroad station, where he ran into a huge crowd laughing and singing and marching southward down the Breydelstraat toward the diamond district. Then turning into the Pelikaanstraat, he noticed that German military officers and

6 M. Steinberg, La Persécution des Juifs en Belgique, Brussels, 2004, table of Judenverordnungen, pp. 307-310.

7 A. Kleiman, op. cit., p. 50. 
Belgian police flanked the crowd on either side. At that point, he fell in with the marchers until able to make his escape, cutting through the Lange Kievitstraat in order to reach home, warn his wife, and barricade his shop ${ }^{8}$. Tellingly, for Kleiman, a Christian neighbor leaned out the window to tell him about the impending onslaught. However, for Kleiman, the neighbor did not offer to help shelter or hide him and his family.

Left to his own devices, Kleiman gathered his wife and daughter into a safe place in the cellar waiting for things to pass through. When morning came, he and other Jews found their shop fronts smashed, wooden blinds shattered, goods and produce of every description littering the streets. Eventually, laws promulgated by the German military administration effectively pushed Jews out of the marketplace as business owners, setting them up to look for wage work, if possible, or otherwise to starve.

Beyond the loss of his radio due to another German mandate in mid-1941, Kleiman spoke little about the occupation through the rest of that year. However, he wrote with shock about the ordinance of 1942 compelling Jews to wear the yellow patch. He shared some of the psychological impacts and provided some important insights between non-Jews and Jews in the wake of this decree. In the first instance, it appeared to him that the non-Jewish population immediately had a sense of superiority.

8 M. Steinberg, La question juive 1940-1942, Brussels, 1983, pp. 155-166 ; M. Steinberg, La persécution des Juifs..., op. cit., pp. 122-128 and Rosengarten, op. cit., pp. 28-29. 
He also surmised that this served as a way for some Belgians who had not made peace with the German occupation to turn their anger toward the Jewish population, a distraction or redirection of sorts. Jews immediately felt a burden. Where, formerly, «we still knew how to talk with Belgians as equals » there grew an immediate unease. «We were ashamed to look into the eyes of a non-Jew », Kleiman observed, " also the Belgians avoided our gaze ». All these changes stood diametrically opposed to the freedom and toleration he had celebrated on his arrival 14 years earlier.

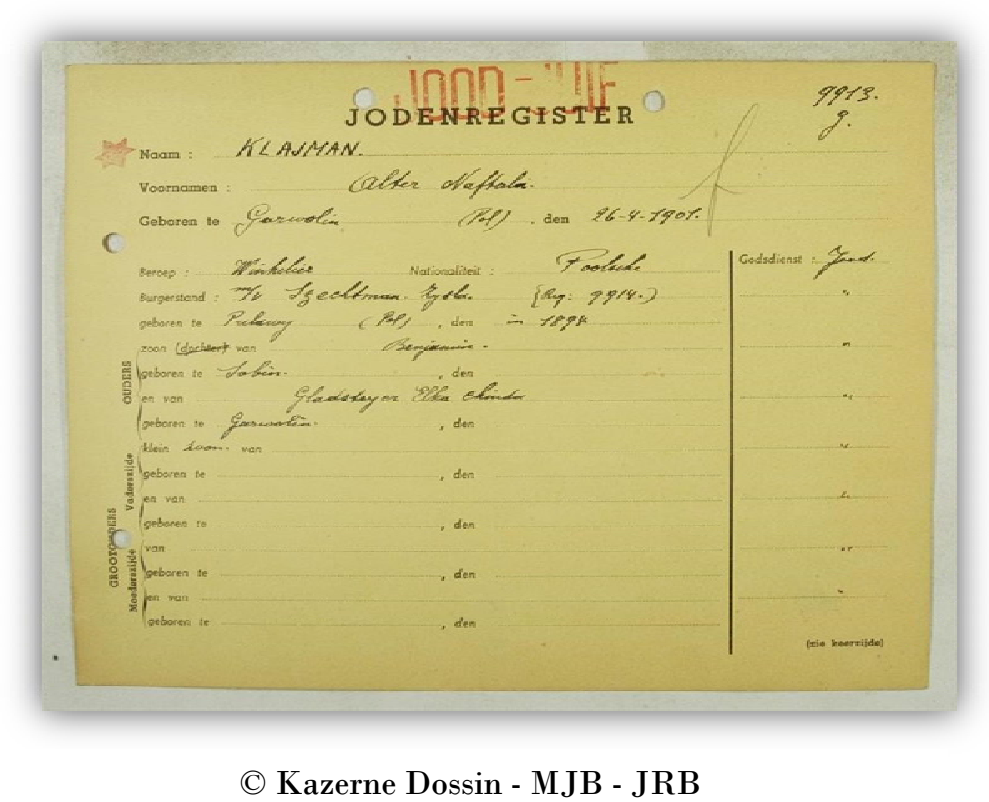

By the summer of 1942, the economic hardship and the psychological pressures made it obvious that Antwerp held no hopes for survival. «The air alone had become soaked with 
repression and fear that everything they say against us can still be used. ${ }^{9}$ While wandering the streets, Kleiman ran into a wellknown, successful Jewish businessman who planned a move to Charleroi and advised him to do the same. Kleiman reasoned that there might be jobs in that city due to the coal-mining region along with factories engaged in wartime production for the Germans. Another factor appealed to him in that the attitude toward Jews in Wallonia remained less strident.

Arriving alone in Charleroi, Kleiman found a room to stay and then headed over to the Association des Juifs en Belgique, the "self-governing" council created by the Germans to provide a centralized authority within the Jewish community whom they could hold accountable for implementing ordinances controlling the Jewish population. Toward early July, 1942, despite the long lines at the Judenrat, despite the fact there were more workers than positions available, Kleiman contacted another friend-of-afriend who managed to get a spot for him doing factory work. However uncertain or disappointing the work, though, Kleiman brought his wife and daughter down to Charleroi. Together they struggled to survive until the factories no longer accepted Jewish workers.

\section{Working in Dannes labour camp}

Desperate, Kleiman answered a German call for work in France under the auspices of the Organization Todt ${ }^{10}$. Noting

\footnotetext{
${ }^{9}$ A. Kleiman, op. cit.

10 A. Kleiman, op. cit., pp. 74-75 ; I. Rosengarten, ibid. Kleiman notes that at the time the Germans presented this as an economic opportunity rather than a summons forced labor. Such might have been the case in order to forestall panic or attempted flight
} 
that this group had a good reputation for its treatment of workers and paying fair wages, Kleiman and his wife debated whether he should, in fact, enlist for the work opportunity while leaving her and his daughter behind. Ultimately he rejected his wife's plea to stay in Charleroi and he stepped into the line of those accepting the work. He headed to a sorting area, never to see his wife and child again. They had returned shortly thereafter to Antwerp where, in a month's time, they ended up in the first German roundup of the Jewish portion of Borgerhout, brought to Mechelen where, loaded on a transport, they died immediately on arrival at Auschwitz.

Once in the sorting section, all the Jewish workers found themselves surrounded by German soldiers with bayonets while the Belgian workers remained unintimidated in this way. Loaded onto a train, he and the others traveled by night and day, finally arriving at the Channel coast, herded into the forced labor camp at Dannes ${ }^{11}$. For the next month, his time there revealed much about the operations of the camp that were corrupt, arbitrary, and deadly. His arrival coincided with the camp's transition from SS control to regular army command; this change brought events that were critical to his survival and escape.

The first among these episodes followed a month of starvation, backbreaking labor, physical abuse and ridicule. After a time, a German propaganda company showed up to film « Jews

among the Jews in Charleroi. See also M. Steinberg, L'étoile et le fusil, vol. 2, op. cit., p. 189.

11 M. R. Roberts, Holocaust and slave labour in Nord-Pas-de-Calais : the Jewish camps, 2016 unpublished (provided by author); also M. R. Roberts, « Footprints in the concrete : a study of the Chemin des Juifs », The Historic Environment, 1, June 2010, pp. 95-127. 
at prayer ». After much debate among several groups of the most orthodox assembled as to who would step out before the entire camp, one unknown man emerged. Wearing a skull cap, phylacteries, and prayer shawl, the unknown prisoner began to chant in Hebrew, praying in earnest.

To the Christian audience and captors, it sounded exotic, certainly not what prayer should sound like to their ears. However, Kleiman and the other Jews heard clearly and completely three of most damning Psalms for Israel's enemies: wishing death, destruction on them, their children, leaving no stones standing on their cities ${ }^{12}$. This renewed a sense of resistance and courage, as well as fostering pride among the Jewish prisoners, providing a motivation to resist succumbing to death at all costs.

A second event revealed the suspected, yet unproven, horror of inmates too ill to work. Wondering why the camp hospital remained empty, Kleiman found out first hand while out on assignment. Digging in the chalk pits about a dozen kilometers from the camp, he moved from one to another, passing one chalk pit filled with emaciated, naked corpses. This drove home the urgency of getting out of the camp. How to achieve this, though ? The issue of health actually held a promise. A physician had appeared in order to treat staff and prisoners after the camp came under military administration. The doctor permitted some prisoners a day or two of time in the barracks before sending them back to work $^{13}$.

\footnotetext{
12 A. Kleiman, op. cit., pp. 79-80. The man recited psalms number 22, 35, 134.

13 On Dannes Camiers : F. Ringelheim, « Les forçats de Dannes-Camiers. Mémoire, mode d'emploi », in Points critiques, 67, 2003, pp. 5-10 ; S. Vandepontseele, « Le travail obligatoire des Juifs en Belgique et dans le nord de la France », in J.-Ph. Schreiber - R. Van Doorslaer (eds.), Les curateurs du ghetto. L'Association des Juifs en
} 
Kleiman conceived a plan to make himself so sick that nothing but a discharge would come from his complaints to the camp physician. He gambled that the few who had been discharged from the camp for "reasons of health" had, after a fashion, managed to escape back into the world of family and religious community. He would join them by forgoing all food. He traded his thin rations for tobacco and smoked and smoked cigarettes by the score until ill with exhaustion. Coming to the doctor after several previous visits where he learned it unlikely that the man would do little more than permit several days of rest, Kleiman proposed a bribe. Cash for release. Meeting Kleiman secretly, the doctor agreed to the deal, but where to get the money?

Upon Kleiman's arrival at Dannes, permission existed for inmates to keep some civilian clothing, including head wear such as caps. Fortunately, he had hidden a significant amount of cash in the bill of his cap, largely British pounds along with Belgian francs ${ }^{14}$. Thus he secured the deal for his own release, assured by a pile of British pound notes. While sharing the news of his impending release, two other men turned to him and began to weep about being stuck in the camp and never seeing their families again. These two were fellow Jews from the same Antwerp neighborhood with whom he shared the top bunk. Turning to one, he asked if he possessed any money or other items of value with which to offer a bribe. Having only a gold watch and chain left in his possession, he despaired. Moved by his neighbor's

Belgique sous l'occupation nazie, Brussels, 2004, pp. 187-231 ; D. Delmaire, « Les camps de Juifs dans le Nord de la France 1942-1944 », in Memor, 8, December 1987, pp. 4765.

14 A. Kleiman, op. cit., p. 90. 
plight, Kleiman took the gold watch and added in many of the remaining 1000 Belgian francs still hidden in his cap's visor ${ }^{15}$. Approaching the doctor with this bargain, Kleiman managed the release of his friend.

Returning once again to the barracks, his other bunkmate from the Jewish district of Antwerp, also began to weep and moan again over never seeing his family again. Heading back to the doctor's barracks, he sought release for the third man. Effectively telling Kleiman that his credit remained in good standing, and that his wife would collect from him at a later date (which she did); the next day all three bunkmates stood ready for release along with other repatriated Belgians.

\section{Returning to Antwerp}

Accompanied by a military guard, the three men left with a slightly larger group others headed for bureaucratic paperwork in Brussels. There they registered with the work bureau and returned home to Antwerp. Hurrying to his shop and home in Borgerhout, Kleiman found his home ransacked, with papers and pictures scattered across the floor. No sign of his family. Across the way on Kroonstraat, an official SS seal covered the front door of his parents' home. They too, obviously swept up. His entire family had fallen victim to the first major sweep of the city's Jews, the first transport gathered at Mechelen to be shipped to Auschwitz where they faced death upon arrival ${ }^{16}$. He

\footnotetext{
15 Ibid., pp. 91-92.

16 Email communication from Kazerne Dossin, deportees passenger list, Convoy no. 1, p. I 5. See also W. Adriaens - É. Hautermann - I. Marquenie - P. Ramet - L. Schram - M. Steinberg, Mecheln-Auschwitz 1942-1944: The destruction of the Jews and Gypsies from Belgium, Brussels, 2009.
} 
could not have known their fate at that time nor would he learn until more than five years after liberation.

Shortly thereafter, a neighbor who had observed Kleiman's return came by with a folded letter that had been dropped by his wife as the transport left from Antwerp. In it, she described how she had left money with a Christian neighbor with whom she had done business. She assured her husband that the woman would return the money and enable him to survive somehow. Within a

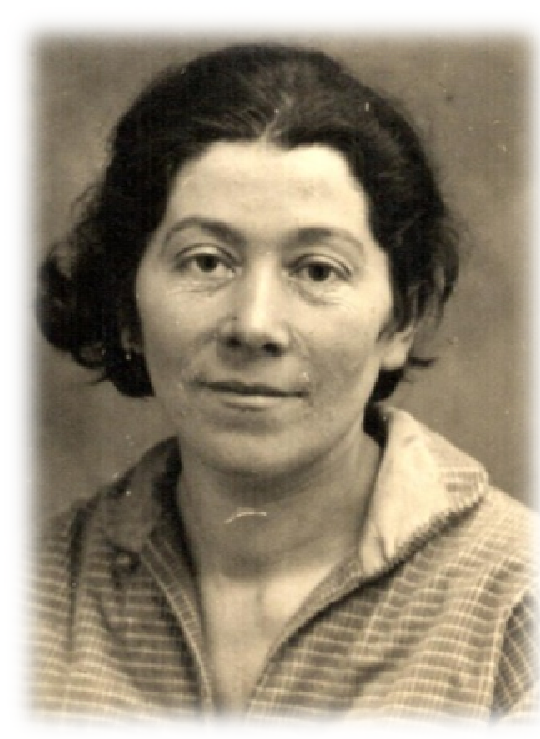
Zysla Szechtman, Alter Kleiman's wife (C) Kazerne Dossin - AGR few days he had hold of the cash and began to figure on the best place to hide securely. July and August of 1942 dealt him a double twist of fate that had saved him, but cost the lives of many others in Antwerp's Jewish community. After responding to the call for labor in France in late July, he ended up in the work camp at Dannes-Camiers for slightly more than the month of August. His release and return in early September came after the first convoys from Mechelen had finished their "deliveries" to Auschwitz. By the same token, his release and return also spared his life, not merely due to escape from the malnutrition, punishing labor, physical and psychological abuse of the camp, but also due to the fact that 
surviving inmates ended up transiting across Europe to die at Auschwitz.

Kleiman remained in his home on Somersstraat during most of September but feared another raid by the Germans. His sense of urgency heightened when he tried to find a different portion of the Borgerhout neighborhood to be safe from any nighttime raid. So, he traveled over to the home of Natawitz, the butcher whom he had helped to escape Dannes, thinking it would be a safer place to spend the night. Natawitz rebuffed his request, fearing that due to his release as an "invalid" the Germans might return to bring him back to the camp. This possibility endangered not only himself but his family. And, given that it was illegal for Jews to spend overnight in any place other than their own homes, such a "stranger" as Kleiman would also provide an excuse to take the entire household away.

Upset, but resigned to this refusal to help, Kleiman decided that the best course remained in a return to Charleroi. Hoping to liquidate as much of his household possessions as possible, he saw a placard set out by the military administration that it had become illegal for anybody to buy Jewish household goods, notably furniture and appliances. Anybody doing so would be fined 20,000 Belgian francs. Nonetheless, he went to a « well-known Belgian by the name of Albert, living by the Vogelmarkt » who refused to purchase anything, but who stated that he would happily hold it for Kleiman pending his return. Albert came by to claim a sofa (the one in which Kleiman and his wife had hidden cash and jewels) and a large gas oven. Spending the night in Albert's home, Kleiman left the next morning in a return to Charleroi. 


\section{Hidden in Charleroi}

Once there he found a distant friend, a community leader who had escape the initial round up. By dint of good fortune, he gave Kleiman a place to hide while securing false papers that permitted his own passage to occupied France with guaranteed work as a tailor. In the meantime, before his departure to France, he found a secure place for Kleiman. A Yugoslav coal miner named Marc, agreed to harbor the fugitive assuming the risk of discovery, but under the condition that Kleiman pay the rent for his cellar flat. Having no choice in the matter, Kleiman and Marc moved through the streets in the early morning until they arrived in a small, two-room basement in the boarding house in the rue du Louvy in Charleroi ${ }^{17}$.

The arrangement worked out, mostly to Kleiman's advantage in finding a hidden shelter. However, toward the end of December of 1942, he worried about having enough money to continue paying rent. His immediate plan called for a dangerous return to Antwerp in order to locate Albert and the sofa stored with him months before, hoping that the sofa's contents had not been discovered. Kleiman ventured out from Charleroi on Christmas Eve. Traveling with the holiday crowd provided some protection along with a reason for taking the train to Antwerp. Lost among the hundreds, if not thousands, going about that night he arrived safely at the station. Despite being questioned briefly by a

17 A. Kleiman, op. cit., pp. 158-159 contain photographs of the original false identity papers with this address. 
plainclothes security officer (so he suspected), he lost himself quickly among the crowds.

Trudging through a heavy rain and sleet, Kleiman mused about the good cheer that emanated from the brightly lit homes : as doors opened to admit guests, he could smell the food, feel the warmth, and see the smiles. Panicking for a moment, he feared that he had lost his way en route to the Vogelmarkt. Recovering his sense of direction, Kleiman found Albert's home, knocking on the front door. The wife answered, then Albert peered over her shoulder. Neither seemed pleased to see him. No greetings. No questions on what had happened. The pair offered only an effort to dispel his presence, to get him go away. Kleiman asked merely to come in and have a place to stay the night. They told him to go sleep in the passenger hall at the station. Despite the sleet and cold, they kept him standing there, but after a few moments, they admitted him. After a bit more talk, they begrudgingly agreed to let him spend the night.

Once they had settled the point of his arrangements for Christmas Eve, he asked to sleep in the living on the sofa rather than kitchen floor. Albert and his wife suddenly became suspicious of his interest in the sofa and barred him from leaving the kitchen. They told that if he did not stay put the entire evening that they would call the Gestapo. Completely dependent on the "hospitality" of the couple, Kleiman agreed. His time for the entire evening through to dawn, Kleiman remained awake, smoking cigarettes, hoping for the chance to slip into the living room in order to reclaim the hidden treasures. At daybreak he dared a look into the living room where he discovered the sofa had been 
torn and ransacked. Shortly thereafter, Albert and his wife then told him to leave.

Heading out on Christmas morning, Kleiman worried about being out alone, commanding attention by his unusual situation. In wandering about, he came upon the residence of old acquaintances. They had been a "mixed marriage" of Jew and German Christian. She escaped police detention by convincing them that the children had come as the product of an adulterous affair with a "pure" German. She welcomed him, despite the surprise, appreciating the risk of being in Antwerp. After some coffee and bread, he asked to stay, pleading the danger of being out in the daylight. While sympathetic, she refused to jeopardize either her children's safety or her own with the possible discovery of a Jew in her residence.

Returning to Charleroi, he worried about the declining funds on hand and what might happen if he were unable to pay the rent. Through the winter of 1942 into the spring of 1943, food became scarcer and his energy waned. At this point, the landlady, Madelyn, came to him with two bread ration cards passed on to her, she said, by a Jewish woman named Fogel. Madelyn ran a black market operation out of the basement where Kleiman hid while Marc the collier worked; these monthly bread ration cards came as payment for some of these hard-to-obtain goods. Kleiman took the cards, sold them, and bought what he needed. This went on for several months until early April, 1943.

Then the Communist underground came to his aid. Madelyn told him that a Jew, whom she had known from before the war came to her looking for Kleiman. She wanted to check to see if it 
would be all right. Having nothing to lose at this point, Kleiman agreed to the visit. The man in question turned out to be somebody whom he had met at Dannes labor camp, traveling around asking Jews if they had anything of value to sell. When asked if he had been receiving help from the underground, Kleiman answered and explained his current state of misery. The mysterious stranger left, but said he would be back, telling Kleiman to answer the door after three knocks. Sure enough, the fellow reappeared carrying two loaves of bread plus preserves. This routine took place for the next three days and Kleiman ate well. Then nothing happened for two weeks until he heard another three knocks on the door.

Opening the door, Kleiman viewed the stranger with suspicion, but the visitor allayed Kleiman's fears by immediately speaking Yiddish right away. Before long he presented Kleiman with two produce ration cards provided by friends in the Charleroi city administration. Despite the cards that he sold for cash to help pay the rent along with purchasing some sugar and other goods, he still struggled to survive. Within a short time, though, the underground committee had heard of Kleiman's situation and agreed to provide him with some cash in hand. It had taken so long for the executive committee to act due to the influence from another Antwerp Jew who had reported to the leadership that Kleiman had become a very wealthy man before the war and did not need any help. Only a site visit by the courier managed to sway opinion in Kleiman's favor.

By the late spring of 1943, Kleiman felt generally secure in his daily survival, yet not necessarily safe from discovery. Through these connections he received false identity papers bearing the 
name of Albert Van Erp, born in Ostend, here in Charleroi to work in the coal mines ${ }^{18}$. With that identity came access to food ration cards that he sold or, alternately, used to purchase scare items and then sell them on the Black Market for a higher price. In this way he developed a modus operandi for survival while in hiding. Concerns regarding rent money diminished significantly.

However, in the small community of the rental house, guests occasionally strayed in to chat, play chess, or sometimes other Yugoslav miners came by in search of Marc. In the last instance, one of Marc's friends recognized Kleiman as a Jew, but promised to say nothing. Anybody who hated the Germans was fine by him. However, Marc advised not to trust the man given his proclivity to talk freely along with a willingness to earn money under most any circumstances. At the same time, from winter into the early spring of the following year, Kleiman recorded increased arrests of Jews who could not tolerate remaining indoors and walked along the streets or into the parks. The majority was swept up, according to his account, by local volunteers working for the SS or were turned in by neighbors.

This worried Kleiman; he had become a courier carrying cash and ration cards to Jewish families several kilometers away, toward the city center. At the same time, a boarder at the house accused him of coal theft and now Marc feared that Kleiman might become the object of revenge : not only turning in a hidden Jew for the bounty, but also condemning Marc as complicit in the deception. Marc noted that the problems had become even worse in this dispute due to the fact that Andre (the fellow boar-

1819 rue du Louvy. He stayed there from the fall of 1942 to nearly the end of the war. 
der) had an SS member as a brother-in-law. It was early spring 1944 and time had come to move.

Through a series of fortunate encounters, Kleiman found a room to rent close the town center at 40 Grand'rue. He noted several important differences between his stay in Antwerp and his Charleroi life-in-hiding that he attributed to a different social climate where the population appeared more inclined toward resistance of every sort, whether active or passive. In one anecdotal episode, two Gestapo men conducted a surprise raid on a home; the father jumped through a window to escape, leaving the young mother and small child behind. While standing at the front door, confronted by these men, the Jewish mother pinched the child in her arms to provoke loud bawling, wailing, and tears. The SS men grew angry at the attention, threatened her with later reprisal, and stormed away. In another episode, a crowd gathered around two Gestapo agents who tried to arrest an elderly Jewish man, shouting and shaming them until they left in frustration.

Yet despite the successful allied landings in June, Kleiman observed that the Germans persisted on the "Jewish front". The Germans offered a reward of 1500 Belgian francs for every Jew turned in. All this took place against the backdrop of deteriorating German authority. Armed bands held up banks and robbed the wealthier farmers. Thefts of coal from the freight terminal nearby increased with frequency even as allied bombing intensified, destroying a glass factory nearby and killing 200 residents. The tensions continued to mount as Kleiman feared a desperate last-minute effort to round up all suspected Jews in an indiscriminate sweep of any and all who seemed suspect. 


\section{A bitter liberation}

The American liberation of Charleroi became almost anticlimactic for Kleiman. Despite release from hiding, the enormous celebrations and other outpourings of public joy, he wrote : « I now felt how miserable I was. I had no friends or family with me to see the liberation. Did I still have something of a family? I then broke into tears. ${ }^{19}$ These feelings continued even after his return to liberated Antwerp. Searching for family that no longer lived there, he waited for news. Women returning from Auschwitz held out hope for his daughter's survival, telling him they had seen her working in the kitchens. Many others remained noncommittal about his wife. So he waited.

Given the dramatic decline in Antwerp's Jewish population after the war, Kleiman moved up in economic status, being promoted from green grocer to diamond merchant. Now able to make a living after the war, he hoped to remake his life, to regain his family and peace of mind. After more than five years of disappointment, he received confirmation of his family's death at Auschwitz. As the final entry into his memoir, Kleiman wrote: "After that I remained a certain time in Antwerp, but couldn't maintain support there, because each stone spoke to me and reminded me of my misfortune. Also, Antwerp had become ugly to me. A Jew had nothing more to do in a foreign land and I traveled to Israel. $»^{20}$ This final statement should not have come as a surprise.

${ }^{19}$ Ibid., p. 204.
${ }^{20}$ Ibid., p. 223. 
Throughout the entire ordeal, Kleiman held fast on to his religious identity and faith, despite the danger or inconvenience to himself. Several examples served to demonstrate his adherence to a modern Orthodox Judaism. When he packed for his trip to the Organization Todt labor camp, he packed this prayer shawl, skull cap, and phylacteries; while in hiding he prayed every morning after his "landlord" Marc went to work. Kleiman worried that he might appear too alien should his protector see him at prayer. Indeed, on one occasion, Kleiman fell asleep wrapped in the tallit (prayer shawl) when Marc return early; Kleiman panicked and told Marc that it was a regular shawl and that he had been cold.

On another occasion, Marc brought home some extra meat, a rare commodity indeed at the time, but it was pork sausage. Kleiman accepted it graciously, saying that he would save it for later. A third instance involved Marc giving him some extra cereal, likely oatmeal, a kind and generous gesture. However, given that it was Passover, Kleiman did not want to eat anything leavened, so he took it and stored it until after the holiday. The incredible hunger that plagued Kleiman all through the German occupation, about which he wrote regularly, made these sacrifices rooted in religious observance all the more memorable.

\section{No place to call home}

Never a fervent Zionist, he nonetheless wondered about the fate of European Jewry, especially after the invasion and occupation of Poland. He fled Poland before the global economic collapse in 1929, built a good life until 1940, and then discovered how unwelcome to native Belgians that he and other Jews had 
become. By war's end, the disappointment became palpable. The discouragement and sense of not belonging anywhere along with a sense of profound loss overwhelmed him. When he wrote about his decision to migrate to Israel in 1950, it became obvious to him that « a Jew had nothing more to do in a foreign land ». Belgium had now joined Poland as a "foreign land". Inhospitable, filled with people whom he could not trust, either Jew or Gentile. There remained no safe haven. No place to call home. Nor is there any evidence to suggest that Kleiman returned from Israel to visit or showed any desire to do so.

When looking at this memoir we find several areas that deserve our attention as we explore the significance of this memoir and its value to Jewish life in occupied and post-war Antwerp. As a primary source, the voice provided by a witness, participant, or victim remain valuable. Despite errors or ambiguities where his testimony relied upon memory, the fears and tension of the moment speak directly to the reader. We have been brought into a story and allowed to share the experiences in way that a scholarly, historical narrative might try to capture. His frustrations with finding any means to survive, of being unable to find trustworthy assistance compels us to imagine our own existence so precariously perched on a daily basis.

A second consideration stems from the value of a case study, of the experiences that focus around an individual, or family, or local community. Historical analysis has relied on such firsthand accounts to guide and enrich the use of other materials. With such a remembrance, we are invited into a story whose contours were shaped by and reflected the shifting realities of larger events. While such a memoir can stand on its own, its 
value has been enhanced by the detailed research that contextualizes events that prompt the writer's responses. Abstract laws and ordinances have been provided with a human face. One cannot know fully the feelings that arose from the limited and generally unfavorable choices that arose in these circumstances, but readers find some meaningful details to help illustrate the moral dilemmas experienced by ordinary people in their struggle to adapt and survive.

Finally, researchers grasp more strongly how the old hopes and promises had died for many Jews without chance for revival in the years after 1945. Kleiman's determination to pursue life afresh resounded with the increased emigration to Israel after 1948. It remains to be see whether the determination to remain in Antwerp, as in Israel Rosengarten's case (see footnote 1), or to emigrate as Kleiman did, represented the broader experience of Antwerp's surviving Jews. Perhaps Rosengarten's youth (born in 1926) played a greater role in his decision; Kleiman (born 1901) had already lost a career and family. The memoir, Oyf Fremden Erd, offers researchers a man's voice whose experiences became intertwined with most every major aspect of the German occupation in Antwerp and Charleroi. 


\section{Note de lecture}

\section{Parcours d'enfants cachés}

\section{Albert Mingelgrün}

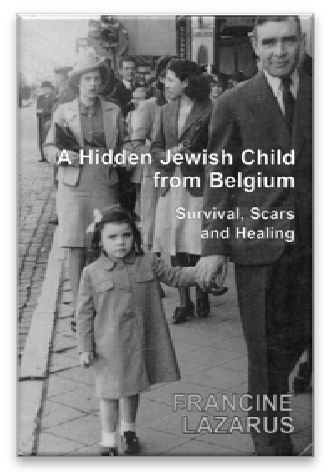

Francine Lazarus, A Hidden Jewish Child from Belgium, Survival, Scars and Healing, Vallentine Mitchell, Londres, 2017, 242 pages.

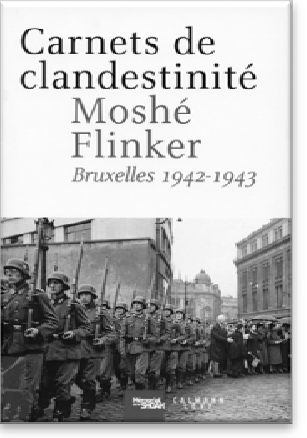

Moshé Flinker, Carnets de clandestinité, Bruxelles 1942 - 1943, Traduit de l'hébreu et annoté par Guy-Alain Sitbon, Préface de Saul Friedländer, Présentation de Nathan Weinstock, Calmann-Lévy, Paris, 2017, 166 pages.

Parus en 2017, les livres de Francine Lazarus et de Moshé Finkler s'ils renvoient tous deux à l'époque de la Seconde Guerre et à l'Occupation de la Belgique, particulièrement de Bruxelles, 
le font chacun sous un angle spécifique et de manière singulièrement attachante.

Le récit de Francine Lazarus développe avec rigueur et précision les aspects qu'implique le titre qu'elle a choisi : enfant juif caché de Belgique, survie, cicatrices et guérison.

Francine Lazarus est née à Ixelles le 12 mars 1938 d'une mère d'origine polonaise, Masza Inberg et d'un père venu de Galicie, Israel Kamerman; elle a déjà un frère aîné, Charles, âgé de sept ans. La famille vit du commerce de tissus et de vêtements

En dépit du soi-disant statut neutre de la Belgique, elle ne tarde pas à être confrontée au régime que l'occupant nazi met progressivement et systématiquement en place et qui impose aux Juifs les mesures inhumaines que l'on sait. Elle voit ainsi des membres de sa famille et des proches disparaître les uns après les autres et se retrouve, à quatre ans, cachée à Saintes, dans le Brabant wallon, ne recevant que de rares visites de son père. ’̀ l'automne 1943, elle rejoint Bruxelles où elle passe également d'un endroit à l'autre encourant de nombreux risques. Fin juillet 1944, deux mois après les débuts de la Libération, son père est arrêté, emprisonné à la Caserne Dossin et fait partie du vingtsixième et dernier convoi pour Auschwitz; elle ne s'en remettra jamais après l'avoir, un temps, vainement attendu, quotidiennement, avec son frère, à la Gare du Midi.

À ce moment-là, en outre, nombre d'enfants survivants se retrouvent entourés d'un mur de silence et face à un refus d'obtenir réponse à leurs questions. Francine fait partie de ceuxlà connaissant, par ailleurs, un sort familial peu enviable : 
négligée et même "mal-traitée" par sa propre mère qui regrette qu'elle n'ait pas suivi son père, qui considère qu'elle est responsable de l'échec d'un remariage alors envisagé, qui contribue à l'envoyer dans un foyer d'adoption, retardant par là jusqu'à huit ans son retour à l'enseignement primaire. Remariée finalement, sa mère la reprend chez elle la faisant s'occuper d'une demi-sœur et de ses grands-parents, et détournant à son profit le montant des réparations de guerre, s'adjugeant dans la suite la plus grande part de la rémunération que perçoit la jeune fille pour des travaux de dactylographie.

Sa situation va néanmoins paradoxalement s'améliorer lorsqu'en 1959, elle est contrainte de quitter la Belgique, avec sa grand-mère devenue veuve, pour l'Australie où vit le reste de la famille. À Sydney, elle est engagée pour travailler à l'ambassade de Belgique en raison de sa connaissance du français. Entrant ainsi de plus en plus dans la "normalité", elle se marie, en 1963, avec un jeune Australien, Phillip Lazarus, s'entend très bien avec sa belle-famille et devient trois fois maman... Cette nouvelle atmosphère existentielle lui permet alors de se retourner vers son passé et de revenir sur son itinéraire d'enfant juif caché. Elle peut donc, par exemple, en 1977, réexplorer les traces personnelles de son antériorité belge, visiter, en 1995, la Caserne Dossin à Malines et participer à la première rencontre internationale des Enfants cachés tout en s'engageant dans le processus de leur reconnaissance officielle comme survivants légitimes, au même titre que les rescapés des camps et se rendre, enfin, à Auschwitz.

Atteignant la cinquantaine, elle se replonge, à Sydney, dans des études supérieures et obtient un Master of Arts. Elle connaît 
aussi la cessation des représailles intergénérationnelles, la famille - avec enfants et petits-enfants - pouvant se réunir, apaisée, en Australie, sa guérison se trouvant par ailleurs symbolisée par son activité de guide au Musée juif de Sydney...

Destruction et reconstruction exemplaire à travers l'histoire fracassée sont donc les maîtres-mots du livre de Francine Lazarus.

En elle toutefois, profondément et à si juste titre, perdure la mémoire de son père : « However, my grief for my father and my guilt that I survived have never subsided. » (Préface, p. XIV).

Ce sont d'autres destins juifs bruxellois que donnent à voir les Carnets de Moshé Flinker.

Quittant La Haye en urgence, la famille Flinker qui comprend, outre les parents, cinq filles et deux garçons, gagne Bruxelles en 1942 après l'obtention de titres de séjour légaux les définissant comme Néerlandais. Il n’empêche, en avril et mai 1944, suite à une dénonciation, les parents, Moshé et deux sœurs sont arrêtés, envoyés à Malines puis à Auschwitz où ils arrivent avec l'avant-dernier convoi, celui du 19 mai : la maman est gazée immédiatement, les deux sœurs survivent tandis que Moshé et son père se retrouvent à Bergen-Belsen et y meurent, sans doute du typhus.

Au lendemain de la guerre, le journal tenu par Moshé entre le 24 novembre 1942 - il a seize ans - et le 6 septembre 1943 est découvert par ses sœurs avec trois cahiers et quelques autres textes. 
Déjà marginalisé à La Haye en raison des obligations et interdictions drastiques imposées aux Juifs, il connaît une situation identique à Bruxelles même si ce n'est pas de manière officielle, d'où le branle donné à l'écriture du quotidien : «Voilà déjà un certain temps que je souhaite écrire, pour moi, chaque soir, ce que j'ai fait dans la journée mais, pour différentes raisons, je n'ai pas pu le faire jusqu’à présent. Ce soir je suis prêt à commencer. » (p. 29)

La pression des événements est trop forte en effet et il est ainsi amené à rapporter, d'une manière générale, les violences qui frappent les Juifs, lesquels « sont arrêtés chaque jour. On dit qu'il y a beaucoup d'informateurs qui livrent aux Allemands les adresses où les Juifs sont cachés. Et, bien sûr, ils payent très bien cette information. J'ai entendu que, pour chaque dénonciation, les Allemands donnaient mille francs (= 325 euros). » (p. 99) En ce qui le concerne personnellement, il raconte, par exemple, qu'un jour, dans le cadre d'une rencontre entre plusieurs jeunes et dans la mesure où son « prénom est rattaché à une catégorie de gens qui est plus ou moins haïe ou en tout cas une catégorie de gens que l'on n'aime pas voir, [...] j'ai changé mon prénom. Certes, dans l'environnement où je me trouvais alors, le changement de prénom avait une signification plus profonde. C'est pourquoi j'ai répondu à leur question: "Oui, je m'appelle - et, encore perdu dans mes pensées - je m'appelle Harry, oui, Harry." Au moment même où je disais cela, il me sembla avoir perdu toute estime de moi. » (p. 145)

Tout cela n'est pas sans peser sur l'atmosphère familiale, alimentant des disputes relatives au parti à prendre : rester en 
Belgique ou tenter de passer en Suisse. Un contexte de cet ordre oblige dès lors le jeune homme à revenir sur le sionisme qu'il tend à considérer moins dans une perspective historico-politique incapable de répondre à l'imperfection du monde et à ses avatars actuels, que sous un angle moral et spirituel seul susceptible de conduire à une « vengeance positive » (p. 150), à savoir « le retour de notre cher peuple sur la terre qui est son héritage. Ce sera la plus grande des vengeances possibles. » (p. 150) Il en est à ce point convaincu qu'il entreprend d'étudier l'arabe afin de vivre en paix avec « les fils d'Ismaël qui eux aussi sont des descendants d'Abraham » (p. 65) et il note ses avancées: «Je continue chaque jour à étudier l'arabe. Cela devient de plus en plus dur, mais je continue malgré tout car cette langue est nécessaire à l'accomplissement de mon objectif » (p. 72) si bien qu'il peut même en venir à observer : « Je progresse de jour en jour dans mes études d'arabe. J'en suis arrivé aux verbes. » (p. 80)

Par ailleurs l'adolescent qu'il est, et légitimement sans recul pertinent, fait preuve d'un réalisme prémonitoire lorsqu'il estime qu' « une victoire des Alliés marquera seulement la fin temporaire de notre souffrance: celle que nous inflige l'Allemagne, mais ce sera le début d'une souffrance encore plus grande qu'auparavant. Au lieu de venir de la seule Allemagne, cette souffrance viendra du monde entier et prendra la forme d'un antisémitisme sans frontière. [...] Il faudra bien trouver des coupables aux crises innombrables qui éclateront après la guerre. » (p. 95)

Ces quelques traits illustrant les tentatives de compréhension et d'explicitation du drame auquel notre jeune auteur est mêlé transcendent, me semble-t-il, le seul intérêt autobiographique de 
ses considérations, combien présent d'évidence et émouvant de surcroît.

Il apparaît donc, en définitive, que les versions spécifiques d'espaces-temps parallèles et poignants que nous livrent Francine Lazarus et Moshé Finkler méritent amplement la lecture... 



\section{Note de lecture}

\section{La langue du III ${ }^{\mathrm{e}}$ Reich}

\section{Jacques Déom}

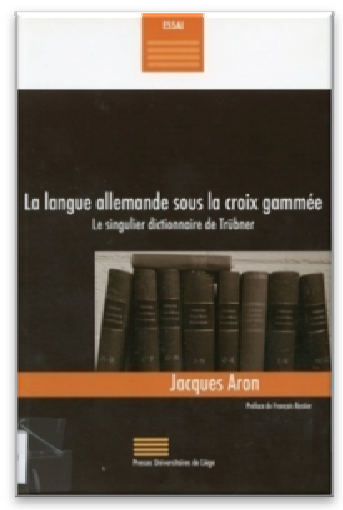

Jacques Aron, La Langue allemande sous la croix gammée. Le singulier dictionnaire de Trübner, Presses universitaires de Liège, Liège, 2016, 160 pages.

Quiconque s'intéresse à la condition des Juifs en Europe et à son devenir ne peut manquer de prêter une attention toute particulière aux développements philosophico-idéologiques survenus en contexte de langue allemande. C'est ce que ne manque pas de faire, depuis plusieurs années, l'essayiste bruxellois Jacques Aron. Outre divers textes mémoriels et autobiographiques ainsi que des études critiques sur l'identité juive, le judaïsme et le sionisme, on doit à cet architecte et urbaniste de formation d'avoir présenté au public francophone, issus du vivier incroyablement fécond de la pensée juive germanique, deux penseurs dont la réflexion, pour être de leur temps, ne laisse pas de s'avérer significative pour le nôtre. C'est ainsi que l'on peut découvrir Constantin Brunner (1862-1937) à travers trois publications où Aron présente et annote sa traduction de Le malheur de notre peuple allemand et nos "Völkisch» (Didier Devillez - Mémoire 
d'Auschwitz, Bruxelles, 2008); Des devoirs des Juifs et des devoirs de l'État (Aden, Bruxelles, 2011); Écoute Israël, Écoute aussi Non-Israël (Les Sorcières), suivi de La nécessaire auto-émancipation des Juifs allemands (Didier Devillez, Bruxelles, 2011). Plus récemment, il a contribué à éclairer la personnalité, qui demeure largement énigmatique pour des lecteurs ne sachant pas l'allemand, de l'auteur de La haine de soi juive dans Theodor Lessing [1872-1933] ou le philosophe assassiné, avec une anthologie de textes traduits par l'auteur (L'Harmattan, Paris, 2014).

Avec La Langue allemande sous la croix gammée. Le singulier dictionnaire de Trübner, Jacques Aron nous propose une étude dont l'importance n'échappera pas à quiconque s'intéresse à l'histoire de la langue allemande et de sa description par la linguistique moderne. Il verse surtout une pièce majeure à l'angoissant dossier de l'imprégnation de la science universitaire par l'idéologie. Produit par une équipe de linguistes entièrement acquis à la philosophie du régime, l'ouvrage en question est en effet le plus important dictionnaire historique et étymologique allemand conçu sous le III ${ }^{\mathrm{e}}$ Reich. Il constitue simultanément le lexique le plus parlant de son idiome - dont tant de mots-clés valent moins comme concepts que comme Leitbilder (images directrices) qui, par leur charge émotionnelle et leur portée symbolique, « articulent le discours chauvin, expansionniste et belliqueux d'une société mise au pas et fortement hiérarchisée (p. 20) » - et apporte sa contribution massive à la systématisation du jargon que Victor Klemperer dénoncera, en 1947, sous 
l'étiquette ironiquement latinisante de Lingua tertii Imperii (LTI $)^{1}$.

Poussant le « nettoyage ethnique » de la langue contre lequel Leo Spitzer s'était insurgé dès 1918, l'ouvrage ne retient que les seuls mots germaniques "de souche", irradiant de surcroît de toute la sacralité de racines qui sont autant de prédéterminations du destin glorieux du peuple locuteur. À mesure que l'on s'avance dans les volumes, l'emprise totalitaire se fait plus évidente, avec une acmé au tome IV (1943), où les entrées apparaissent surchargées de citations des idéologues de référence : Hitler évidemment, mais aussi Goebbels ou Rosenberg, entre autres.

Engagé en 1934, le projet est porté par le Groupe d'Études pour la Recherche lexicologique allemande - Arbeitsgemeinschaft für deutsche Wortforschung. Les quatre premiers volumes voient le jour entre 1939 (le tome 1 en mars très exactement, soit six mois avant l'invasion de la Pologne) et 1943. Il sera poursuivi au-delà de l'effondrement du régime et dans le nouveau contexte politique (occupation militaire, guerre froide, division de l'Allemagne) puisque, au terme d'une décennie de latence, les quatre derniers tomes paraissent entre 1954 et 1957. Jacques Aron: «La cohérence de l'ouvrage dans les circonstances que l'on sait sera d'autant plus rudement mise à l'épreuve que l'ordre alphabétique impose une chronologie de l'exposé et des renvois inévitables entre les différentes entrées du dictionnaire. Les auteurs se trouvent donc devant un véritable casse-tête permanent. Et c'est ce défi involontaire qui, par le texte et aussi par ses non-

1 V. Klemperer, LTI, la langue du IIIe Reich, Paris, 2003 ; L. Spitzer, Traque des mots étrangers, haine des peuples étrangers. Polémique contre le nettoyage de la langue, Limoges, 2013. 
dits, par les apparitions et disparitions de ses exemples et références nous servira de révélateur des ressorts profonds et des contradictions de ce projet. » (p. 14) La matière des nouveaux volumes a subi le traitement d'une « dénazification » intellectuelle des plus ambiguës : les notices estompent les références à des idéologues disparus avant la défaite du Reich et voient apparaître quelques auteurs juifs, essentiellement de complexion réactionnaire, mais restent substantiellement fidèles à leur inspiration initiale : nombre de références littéraires s'appuieront, même dans les volumes d'après-guerre, sur des auteurs notoirement connus pour leurs positions pangermanistes, racistes et antisémites.

En décrivant dans son contexte l'aventure éditoriale que constitue le Trübner et en fournissant une analyse précise d'une centaine de ses entrées (indexées en fin de volume), Jacques Aron rappelle un épisode peu glorieux de l'histoire de l'une des principales Geisteswissenschaften, la linguistique, et en l'espèce de son asservissement enthousiaste à la moins humaniste des idéologies. Linguistique allemande, serait-on tenté de préciser, en rappelant le rôle central du fait linguistique (et de la conscience qui s'en est développée) dans la constitution de l'identité nationale. « L'idéalisme, qui croit à l'autonomie et aux vertus intrinsèques de la pensée et de la langue qui la supporte, y tient une place plus importante que chez ses rivales et modèles, la Grande-Bretagne et la France. Avant d'être un espace politiquement unifié, l'Allemagne n'est-elle pas d'abord et pendant longtemps un espace imaginaire autour d'une culture incarnée par sa langue, et singulièrement par le mythe d'une langue "maternelle" originaire, la mère nourricière précédant la "patrie", le Vaterland, la terre du père ? » (p. 15). Mais l'étude de Jacques Aron est égale- 
ment lestée d'un intérêt d'actualité. D'abord par la réflexion qu'elle ravive quant à l'autonomie, théorique et institutionnelle, de la recherche scientifique à l'endroit du contexte où elle s'inscrit. Mais tout autant parce qu'elle devrait servir d'instrument de travail à tous ceux, littéraires, philosophes, sociologues, historiens, à qui, travaillant sur l'ère germanique, risquent d'échapper, dans les textes qu'ils pratiquent dans un allemand dont ils ne maîtrisent pas toujours les subtilités, certaines connotations essentielles. Telle polémique sur les textes de Martin Heidegger dans les années 30 en fait foi... Les volumes du Trübner ont été acquis au fur et à mesure de la publication par toutes les bibliothèques universitaires et ont constitué une référence obligée pour des générations de philologues germanistes. Par le mélange sinistre d'érudition, de militantisme forcené et d'opportunisme qu'il illustre, il fournit un témoignage éloquent sur les aléas que peuvent connaître les sciences humaines. On saura gré à Jacques Aron d'avoir attiré notre attention sur lui.

On signalera également l'étude du même auteur consacré à un penseur de l'Aufklärung tardive : Saul Ascher. Un philosophe juif allemand entre Révolution française et Restauration prussienne, suivi de La Germanomanie (1815) et La Célébration de Luther sur la Wartburg (1818), adaptés et annotés par Jacques Aron, L'Harmattan, Paris, 2017, 105 pages. On découvrira dans cette présentation suivie de deux traductions de textes essentiels la réflexion lucide d'un philosophe autodidacte sur la situation précaire des Juifs, qui risquent de faire les frais des tensions nées dans l'espace allemand du fait des guerres napoléoniennes. À une entité germanique dont l'unité est essentiellement linguistique, mais clivée depuis la Réforme par l'opposition des catholiques et des protestants, s’ajoute la mémoire fraîche des attitudes adop- 
tées vis-à-vis de l'envahisseur par les divers États allemands, alliés ou adversaires de la France. La Prusse a été occupée pendant six ans. Au lendemain de Waterloo, l'Allemagne peine à trouver sa voie dans un contexte où les structures féodales un temps mises sous le boisseau retrouvent de leur vigueur. L'émancipation décrétée par la Révolution française a certes allumé un phare pour tous les Juifs d'Europe. Il s'en faut que ses promesses trouvent à se réaliser en terre germanique... 